\title{
HET MONOPOLIEBEGRIP BIJ FRANZ OPPENHEIMER IN VERBAND MET ZIJN UITBUITINGSLEER.
}

In de volgende regelen wil ik pogen het monopoliebegrip, dien hoeksteen van het leergebouw van Oppenheimer, aan een critisch onderzoek te onderwerpen. De hoofdreden, waarom de ,burgerlijke" of „universiteitseconomie" in het algemeen zoo weinig weten wil van het liberale socialisme, acht ik gelegen in de fundamenteele dwaling, waarvan de Frankfurt'sche hoogleeraar doet blijken bij zijn conceptie van wat onder monopolie moet worden verstaan. En het komt mij voor, dat hier voor de critiek het aangrijpingspunt bij uitnemendheid moet worden gezocht, wijl al het andere: de uitbuiting, de crises, het verschil tusschen potentieele en feitelijke welvaart, het economisch karakter der categorieën grond en kapitaal, de verklaring van ontstaan en hoogte van het "arbeidsvrije" inkomen met en benevens het sociaal-politieke oordeel daarover, het lot der monopoliegedachte - juist of onjuist zal deelen. Het verband tusschen een en ander is niet minder nauw dan bv. dat tusschen. de arbeidswaardeleer van Marx en díens bewijs van de meerwaarde.

Monopolie staat tegenover concurrentie. Het eén verdraagt zich zoo goed met het ander als water met vuur. Men kan wel met Oppenheimer onderscheiden tusschen vrije en beperkte concurrentie, doch wanneer de bedoeling daarvan is de mogelijkheid van een samengaan of samenvallen van monopolie en beperkte concurrentie op hetzelfde gebied van het bedrijfsleven te suggereeren, dan kan daarin alleen een verwateren van op zich zelf duidelijke en scherpe begrippen worden gezien. Er kan slechts sprake wezen van een monopolie, wanneer alle concurrentie - beperkte zoo goed als vrije - ontbreekt. Op dit cardinale punt staat tegenover Oppenheimer's meening vierkant de mijne. Vóór ik deze nader ontwikkel, moge een uiteenzetting van Oppenheimer's monopolietheorie voorafgaan.

In het briljant geschreven boekje „Der Ausweg, Notfragen der Zeit" onderscheidt Oppenheimer twee klassen van monopoEcon. 1921. 
liën: „das absolute Monopol und die beschränkte Konkurrenz”. Hooren wij, wat hij onder beide verstaat. „Ein absolutes Monopol besteht dort, wo ein Einzelner oder eine zu gemeinsamer Preispolitik verabredete Gruppe die alleinige Verfügung über ein stark begehrtes und deswegen über seinen Arbeitswert bezahltes Produkt besitzt. Einzelmonopolisten sind der Besitzer des Rüdesheimer Bergs und des erfolgreichen Patents; die Gruppe spielt in der kapitalistischen Welt der Kartelle, Syndikate und Trusts eine sehr grosse Rolle. Hier vereinigen sich die säntlichen Produzenten (oder mindestens die grosse Mehrzahl) eines an sich beliebiger Vermehrung fähigen Erzeugnisses, z. B. von Schienen oder Draht, in dem Vertrage, ihre Erzeugung einzuschränken; dann kommt weniger auf den Markt, und der Preis steigt über den Arbeitswert.... Die zweite Hauptklasse der Monopole trägt den Namen der ,beschränkten” Konkurrenz. Sie ist gegeben, wenn mehrere Besitzer eines nicht beliebig vermehrbaren Gutes, das stärker begehrt als angeboten wird, miteinander konkurrieren. Hier steht auch ohne Verabredung der Monopolisten der Preis auf die Dauer und im Durchschnitt über den Arbeitswert. Denn die Käufer überbieten sich in ihrer dringlichen Nachfrage. So sind die ungeheuren Wucherpreise für Lebensmittel während dieser Kriegszeit zustande gekommen." Nog verdere onderscheiding moet worden gemaakt. In beide klassen kan nl. òf de voorraad absoluut te klein zijn (radium) òf de voorraad de behoefte zelfs belangrijk te boven gaan, mits die voorraad tegenover de vragers kan worden ,gesperrt": „Hier entsteht das Monopol durch Monopolisierung". En terwijl Oppenheimer zegt, dat alleen dit laatste geval ons hier interesseert, komt hij al spoedig tot de toepassing in den uitroep: „Dieses Gut ist der Grund und Boden!"

Bezien wij echter zijn monopolie-omschrijving eens wat nader, met name de klasse der beperkte concurrentie. Het niet naar welgevallen vermeerderbare goed wordt sterker gevraagd dan aangeboden. Bedoeld is: tot den arbeidsprijs. De aequatie komt hooger te liggen en de wederpartij betaalt een meerwaarde, wordt uitgebuit in dier voege "dass der Kontrahent mehr Arbeitsstunden gibt als er empfängt." Nu kan dadelijk worden gevraagd: wat bedoelt Oppenheimer met een niet naar willekeur vermeerderbaar goed? Dat de natuur, als bv. bij den grond, vrijwel onoverkomelijke hinderpalen aan de toeneming in den weg stelt? In 
dit geval ware, evengoed als bij zeldzame schilderijen van gestorven meesters, een zeldzaamheidswaarde toe te geven, die men tot zekere hoogte monopoliewaarde zou kunnen noemen. Tot zekere hoogte, want zoodra de prijs van het goed boven de aequatie kwam te liggen, zou de (beperkte) concurrentie der verkoopers de afgevallen vragers weer uit hun tent lokken tot het evenwicht zou zijn hersteld. In dit geval zou bij niemand de gedachte aan een monopolie opkomen. Alleen de constructie der arbeidswaarde, die n.b. bij den grond niet is te bepalen, kan er toe brengen in den hoogeren evenwichtsprijs nu ook een echten monopolieprijs te zien. Wat hij niet is.

Evenwel, Oppenheimer bedoelt niet met deze tweede hoofdklasse zijner monopoliën goederen, die om natuurlijke redenen geen vermeerdering toelaten, zooals de grond. Hij gaat veel en veel verder. Op blz. 25 van genoemd ..boekje stelt hij de vraag: „Wie kann der. Unternehmer die Arbeitsleistung unter ihrem Werte kaufen ? - Der Leser weiss die Antwort bereits. Weil der Arbeiter mit seinem Unternehmer unter einem Monopolverhältnis tauscht! Darum verkauft er seine Arbeitsleistung unter ihrem Werte, und darum kauft der Unternehmer sie unter ihrem Werte, ihrem vollen Ertrage. Der Arbeiter zahlt für das Lohngeld mit zuviel Arbeit, oder: er erhält für seine Arbeit zu wenig Lohngeld.” En hij laat nog volgen: „Auch der Zins ist der Mehrwert eines Monopols. Der Schuldner braucht des Geld dringender, als der Gläubiger den Wunsch hat, es los zu werden: zwischen ihnen besteht ein Monopolverhältnis." Hier wordt dus van het kapitaal, dat in arbeidspraestaties of schuldvorderingen wordt belegd, hetzelfde gezegd als straks van den grond: monopolie. En waar er geen reden is, van een absoluut monopolie te spreken, zal kapitaal, evenals grond, onder de klasse der niet willekeurig vermeerderbare goederen vallen. Maar nu vraag ik! Is er niet, waar scherpe concurrentie tusschen ondernemers bestaat, waar banken met elkaar strijden om deposito's te trekken en de beste beleggingen te verkrijgen, waar van de talrijke arbeidsmarkten er niet weinige zijn, welket positie aan sonmige groepen van arbeiders een overwicht geeft op het kapitaal, verblinding noodig om te kunnen volhouden, dat de ondernemer aan zijn profijt komt door onderbetaling van den arbeid? Staat kapitaal met grond op één lijn, waar het gaat om het monopolie-kenmerk ,eines nicht beliebig vermehrbaren Gutes" ? Het is maar de vraag, wat 
men onder „beliebig” wil verstaan. Willekeur is er niet bij de kapitaalvermeerdering. Maar wel is vol te houden, dat, zoo er maar voordeel in steekt, besparing en kapitaalvorming op kosten van de vertering toenemen, met als eenige grens het maatschappelijk inkomen onder aftrek van de noodzakelijke afschrijvingen en het "noodzakelijk" levensonderhoud. De natuur biedt hierbij de behulpzame hand, maar aan grondvermeerdering zet zij den voet dwars.

Het is duidelijk, dat Oppenheimer monopoliewaarde met waarde in het algemeen heeft verward. Wanneer de kapitaalrente verkregen wordt door den arbeiders niet te geven wat hun in en door de waarde van het arbeidsproduct toekomt, wanneer zij dus een aftrek zou zijn van het natuurlijke loon, en wanneer dat alleen mogelijk is door een monopolistische overmacht van kapitaal op arbeid, dan kan daaraan alleen een einde komen door aan het kapitaal alle maatschappelijke ruilwaarde te ontnemen. De kapitaaldienst heeft in het verkeer een waarde, die in de rente haar uitclrukking vindt. Verdwijnt de rente, dan wordt de kapitaaldienst waardeloos en is, ondanks het manifeste te-kort aan kapitaal, elke rem tot economisch gebruik weggenomen. $\mathrm{Er}$ is dan niet alleen geen monopoliewaarde meer, doch alle waarde is weggevallen. Terwille van de uitbuiting moest Oppenheimer ook bij het kapitaal aan het monopolie vasthouden. Gaf hij toe, dat kapitaal een "beliebig vermelirbares Gut" was, waar bleef de meerwaarde? Hij heeft, misleid door zijn onnatuurlijk monopoliebegrip, den economischen aard van het kapitaal ten eenenmale miskend, met het gevolg, dat verdwijning van het kapitaal"monopolie", d. i. van de rente, ${ }^{1}$ ) het kapitaal zelf als economische categorie zou te-niet doen. Want wat is kapitaal zonder waarde?

De „Bodensperre” als „Sperre” staat op één lijn met allen overigen eigendom. Wat voor den één eigendom is, wordt daardoor onthouden aan alle anderen. "Sperre" zonder meer kan nooit een monopolie vestigen. Ook niet de omstandigheid dat aan het goed een te-kort bestaat in absoluten-zin. Want dit geldt immers van alle niet-vrije goederen, en zoo zouden deze alle tot de monopolie-afdeeling gaan behooren. Dit ware ongerijmd, en vandaar Oppenheimer's criterium der ,beliebig reproduzierbaren

1) Gesteld: zij ware mogelijk. $Z_{\mathrm{ij}}$ is dat niet. 
Gïter." 2) Maar wat geeft nu aan Oppenheimer het recht, van deze categorie het kapitaal uit te zonderen en de kapitaalrente tot een monopolieprijs te stempelen ? Hij zegt: „Bei den Naturdingen haben wir noch einmal zu unterscheiden zwischen denjenigen, deren Angebot bei steigender Nachfrage, und das heisst: bei steigenden Preisen, beliebig vermehrt werden kann, einerseits, - und denjenigen, deren Angebot bei steigender Nachfrage nicht vermehrt werden kann, anderseits." Dit is "die natürlich bedingte ökonomische Seltenheit". Nu staat toch één ding vast: ook kapitaal kan een "Naturding" zijn, bv. steenkool. En Oppenheimer rangschikt dit specimen uitdrukkelijk onder de goederen, die bij stijgenden prijs vermeerderbaar zijn, dus monopoliekarakter ontberen. Zoo zou dus kool als kapitaal volgens Oppenheimer op het monopoliekarakter aanspraak hebben, en als „,beliebig reproduzierbares Gut" hetzelfde karakter derven!

Tegenover of liever boven die natuurlijke zeldzaamheid, welke alleen aan „Naturdinge" wordt toegeschreven, staat de ,rechtlich bedingte ökonomische Seltenheit". En de groep van goederen en diensten, welke hiertoe behoort, is steeds in monopoliepositie. Met de "Naturdinge" is hier afgehandeld, zoodat dan het grootste deel van het kapitaal tot deze monopolierubriek ware te brengen. Maar nu mag toch worden gevraagd, waar Oppenheimer dit vandaan haalt? Er zijn zeer zeker kapitaalgoederen in zuivere monopoliepositie, en deze toestand kan zoowel door natuurlijke als juridische factoren zijn verwekt, doch van verreweg de meeste, en van het kapitaal als categorie geldt onweersprekelijk, dat ",dessen Angebot bei steigenden Preisen (in casu rente) beliebig vermehrt werden kann." Toch moeten de arbeiders meer arbeidsuren afstaan dan $z i j$ in hun loon terugontvangen, toch staan $z$ ij meerwaarde af, ondat $z i j$ tegenover het monopolie van den ondernemer machteloos zijn hun volle arbeidsproduct als loon op te eischen!

Oppenheimer's monopolieleer is, toegepast op kapitaal, in vierkanten strijd met de feiten. $Z \mathrm{Zij}$ is bovendien met zich zelf in strijd, waar toegegeven wordt dat goederen als steenkool 3 ) ,,beliebig

2) Vgl. Theorie der reinen und politischen Oekonomie, 1919, blz. $378 \mathrm{v}$.

$\left.{ }^{3}\right)$ Een beter voorbeeld dan steenkool, welker productie op roofbouw steunt en waarvan dus niet kan worden gezegd dat zij behoort tot de „beliebig. reproduzierbaren Giiter", -ware de veestapel eener volkshuishouding, waarvan èn het kapitaalkarakter èn de on-monopolistische vermeerderheid onomstootelijk vaststaan. 
reproduzierbar" zijn, terwijl zij desondanks deel uitmaken van het kapitaal-monopolie.

Maar dan hangt ook de uitbuitingsthesis, als verklaringsgrond voor de kapitaalwinst, in de lucht. Dan loopt niet alleen de arbeider het kapitaal, doch ook het kapitaal den arbeider achterna. Dit zal geschieden, wanneer de rente stijgt, het kapitaalaanbod toeneemt waardoor de stijging weer wordt getemperd, en de vraag naar arbeid zich met meer drang doet gelden.

In dit verband wil ik nog op iets zeer eigenaardigs bij Oppenheimer wijzen, waaruit blijkt, hoe zijn eenzijdigheid hem verleidt tot het ergste, wat een wetenschappelijk man kan overkomen: meten met twee maten. In het hoofdstukje over „Die Götzendämmerung des Unternehmerprofits", waar ons Duitschland als een vrije kolonie voor oogen wordt geplaatst, doordien het grondmonopolie is opgeheven, wordt ons de komende heerlijkheid o.a. met deze woorden geschetst: „Die Industrie in allen ihren Zweigen und Handel und Verkehr wissen sich vor drängenden Aufträgen nicht zu bergen: sie bestellen in Massen Arbeit- und Lohnsparende Maschinen und vermehren dadurch nur die Nachfrage nach Arbèiten ins Kolossale. Unter solchen Umständen: stark gesunkenes Angebot bei dringendster Nachfrage, ,ist die Konkurrenz ganz auf Seiten der Unternehmer"; zwei Unternehmer laufen jetzt immer einem Arbeiter nach und überbieten sich, statt dass, wie bisher, immer zwei Arbeiter einem Unternehmer nachliefen und sich unterboten." Zoo zal dan de meerwaarde verdwijnen, meent Oppenheimer. $\mathrm{Hij}$ vergeet, dat onder die omstandigheden de arbeidskracht niet "beliebig "reproduzierbar" is geworden, dat het monopolie, in Oppenheimer's stelsel, zich heeft verplaatst van kapitaal naar arbeid, en dat nu het loon zal stijgen boven de natuurlijke waarcle van den arbeid, m. a. w. de ondernemer zal worden uitgebuit doordien hij meer arbeidsuren moet afstaan dan hij in de arbeidspraestatie terug ontvangt! Zoo ziet de theorie, mits consequentie blijft betracht, er uit. $\mathrm{Er}$ is geen ontkomen aan. Oppenheimer zelf verklaart de „beschränkte Konkurrenz eine Abart des Monopols". .Welnu: wanneer twee ondernemers voortaan één arbeider moeten naloopen, is er dan niet „,beschränkte Konkurrenz" aan arbeidszijde gekomen, en stijgt dan niet het loon boven de natuurlijke waarde van den arbeid ? !

Het monopoliekarakter van kapitaal is dus een fictie. De uitbuiting van den arbeider op grond van dat karakter wordt tot 
een onbewezen bewering. Er zijn nog meer conclusiën uit het voorgaande te trekken en dan blijkt eerst recht, dat in Oppenheimer's monopolie-opvatting de hoeksteen van heel zijn leergebouw is te zien.

Ik heb het oog op Oppenheimer's leer, dat de omvang van de productie door de consumptie wordt bepaald. Het verschijnsel der onderbetaling van de arbeidskracht, der meerwaarde dus, is de oorzaak, dat de potentieële voortbrenging nimmer wordt verwezenlijkt, dat de rentabiliteit een spaak in het wiel steekt bij de toepassing van de nieuwste technische vindingen. Het massaverbruik wordt door de meerwaarde kunstmatig laag gehouden. Vandaar dat er zoo spoedig geen „vraag” meer is, wanneer een of andere productie zich uitzet. Kreeg de arbeider de volle waarde van zijn arbeidsproduct, zoo zou de gestegen arbeidsproductiviteit steeds een afvoerkanaal vinden in de toegenomen vraag van arbeiderszijde. Er zouden, wijl arbeidsproduct en arbeidsloon eigenlijk twee kanten zouden wezen van éénzelfde zaak, geen crises meer behoeven voor te komen.

Onnoodig te zeggen, dat dit heele betoog staat en valt met de juistheid van de monopolie- en uitbuitingsthesis. Oppenheimer's crisisleer kan het zonder de meerwaarde $=$ ingeperkt massaverbruik niet stellen. Maar bovendien! Laat een oogenblik de uitbuiting als principe der kapitalistische productie zijn toegegeven. Wat dan nog?

Hier kom ik aan de in menig opzicht uitnemende critiek, door H. Oswalt in 1919 uitgebracht onder den titel „Falsche Rechnungen, eine kritische Auseinandersetzung mit der Oppenheimer-. schen Theorie." Zoo beknopt als deze in lapidairen stijl geschreven brochure van Oswalt (slechts 23 blz.) is, dringt ze toch door tot het merg van het stelsel, en rekent zij, in groote trekken, daarmede ,endgültig" af. Oswalt legt aan zijn beschouwingen ten grondslag het geschrift van Oppenheimer, getiteld „Die soziale Frage und der Sozialismus, eine kritische Auseinandersetzung mit der Marxistischen Theorie."

Wat het achterblijven van de mogelijke bij de feitelijke productie betreft, merkt Oswalt op, dat Oppenheimer deze stelling niet bewijst: hij ,stellt einfach die Behauptung auf, als ob sie keines Beweises bedürfte." En hij vervolgt: „Nur eines könnte etwa als der Versuch einer Beweisführung gemeint sein: wenn die Menschen sechsmal soviel Schuhe kaufen wollten, als zie 
heute kaufen, dann wären wir im Stande sechsmal soviel Schuhe zu produzieren. Das mag zutreffen, wenn wir annehmen, dass die Menschen sich bereit fänden, den Mehrkonsum an Schuhen durch Minderkonsum an andern Gütern auszugleichen. Dass wir aber von allen Gütern gleichzeitig im richtigen Verhältnis mehr produzieren könnten, ist damit nicht bewiesen, bleibt viel mehr eine vollständig beweislose Behauptung." En nu het tweede punt: het loonstelsel vermindert de koopkrachtige vraag der massa. Hierop repliceert Oswalt: „Nun ist es unbestreitbar, dass die Massen, oder die Unterklasse, wie der Verfasser sich sonst ausdrückt, mehr Kaufkraft besässen, als sie heute besitzen, wenn ihnen neben dem Lohn der Teil des Produktionsertrags, den er Mehrwert nennt, zuflösse. Aber was folgt daraus? Wir dürfen eine ganz elementare Beweisführung nicht scheuen. - Wenn A dem $B$ einen Ring für hundert Mark verkauft, so tritt folgende Veränderung ein: vorher besass A den Ring und B die hundert Mark, jetzt besitzt B den Ring und A die hundert Mark. Aber die Zahl der existierenden Ringe und die Menge des existierenden Geldes ist weder grösser noch kleiner geworden. Freilich, eine weitere Folge kann eingetreten sein, wenn nämlich der Kaufpreis dem Werte des Ringes nicht entsprach. War er zu hoch, so ist A reicher, $B$ um denselben Betrag ärmer geworden, als er vorher war; war er zu niedrig, so ist es umgekehrt. Aber A und B zusammen sind in jedem Fall nach dem Kauf gerade so reich, wie sic vor dem Kauf waren. So selbstverständlich diese Wahrheiten sind; so sind sie eigentümlicher weise doch oft verkannt worden.... Wie nun aber, wenn wir an die Stelle der Ringe die Arbeitsleistungen setzen und unter dem A die „Unterklasse”, unter dem B die „Oberklasse". verstehen ? Selbstverständlich wird auch dann zu sagen sein: die gesamte Kaufkraft bleibt dieselbe, ob nun die Umsätze zwischen den Verkäufern der Arbeitsleistungen und den Käufern. dieser „Ware" zu einem höheren oder zu einem geringeren Preise abgeschlossen werden; ob der "Melirwert" dem Arbeiter oder dem Kapitalisten zufliesst. Est ist gewiss keine bedeutungslose Frage, ob ein Teil des volkswirtschaftlichen Ertrages dieser oder jener Gesellschaftsklasse zuteil wird; das ist sogar von der höchsten sozialen und kulturellen Bedeutung. Aber für unsere Untersuchung, ob durch das bestehende Lohnsystem die „Kaufkraft” der Gesamtheit vermindert und dadurch der Produktion eine Schranke gesetzt wird, ist sie 
bedeutungslos. Was nach Beseitigung des Mehrwerts die einen mehr kaufen könnten, könnten die anderen weniger kaufen; die Subjekte der Kaufkraft würden sich verändern, ihr Umfang aber würde derselbe bleiben."

Werpt men tegen, dat de hoogere klasse reeds zóó verzadigd is met goederen van allerlei aard, dat deze thans haar koopkracht niet vol kan aanwenden, dan antwoordt Oppenheimer's criticus terecht, dat ook vermeerdering van kapitaal aanwending van koopkracht is. De vraag richt zich niet alleen op genotsgoederen, maar ook op productiemiddelen. En hij concludeert m.i. volkomen juist: „Dass eine Verschiebung der Kaufkraft innerhalb der Volkswirtschaft zugunsten der Unterklasse gleichbedeutend wäre mit einer Vermehrung der volkswirtschaftlichen Kaufkraft, das ist die falsche Rechnung, die wir Oppenheimer vorwerfen."

Mr. Dr. A. Spanjer, in zijn belangrijk academisch proefschrift over ,Het liberale socialisme", sluit zich bij deze ,,,kern en hoofdzaak" van het stelsel geheel aan. ${ }^{4}$ ) De schrijver gewaagt van ",de insnoering van het verbruik", waardoor het voortbrengend vermogen stuit „op een kunstinatige rentabiliteitsgrens". Ook zijn gedachtengang is, dat veeleer aan den omvang van het verbruik dan aan dien der productie de maatschappelijke welvaart kan worden gekend. Bij stijging van de loonen neemt de koopkrachtige vraag en daarmede de productie toe. De rentabiliteitsgrens wordt dan vooruitgeschoven. Deze redeneering miskent ten eenenmale, dat koopkrachtige vraag aanbod onderstelt. Zal de koopkrachtige vraag in haar geheel zijn toegenomen, dan is dit een andere uitdrukking voor adaequaat vermeerderd aanbod. Hoe meer men heeft aan te bieden, hoe grooter de koopkracht. Meer vraag in totaal lokt dus niet meer-productie uit, doch is meer-productie. Wanneer in een volkshuishouding eenerzijds het aangebodene, anderzijds het gevraagde wordt samengeteld, dan blijkt er tusschen beide quanta identiteit te bestaan. Nog afgezien van Oswalt's juiste opmerking, dat minder-verbruik en minder-vraag op ander gebied meer-vraag oproept, is het een theoretische en praktische onbestaanbaarheid, dat opvoering van het totaal-verbruik zou leiden tot grootere productie. Want er wordt alleen meer verbruikt bij gestegen koopkrachtige totaal-vraag, en deze laatste is identiek met vermeerderde totaal-voortbrenging. Zoo

4) Blz, 228 . 
beduidt ,ingesnoerde vraag" verminderde voortbrenging, die niet tot elkaar staan als oorzaak tot gevolg, omdat $z$ ij hetzelfde zijn.

Het maakt een tragi-komischen indruk, wanneer wij den schrijver op dezelfde bladzijde 228 hooren gewagen van de hoogst onbillijke verdeeling in de tegenwoordige maatschappij ,die de arbeidende massa niet veel meer dan een fixum voor noodzakelijk levensonderhoud toekent." Weet Mr. Spanjer niet van loonen in de bouwvakken, van stucadoors e.d., die te Amsterdam reeds tot f 125:- in de week zijn geklommen, waardoor deze arbeiders, die werkelijk niet zoo veel behoeven te kennen en vaak zeer middelmatige vaklieden zijn, in inkomẹn op één lijn staan met zeer hooge departementsambtenaren en maar weinig minder verdienen dan een gewoon hoogleeraar op aanvangssalaris? Een fixum voor noodzakelijk levensonderhoud!

Het oneconomische in de redeneering, die meent, dat consumeeren zoo'n prachtig werk is, ondat daardoor de rentabiliteit wordt bevorderd en de productie verhoogd, terwijl toch consumeeren niets anders is dan opmaken, moge hier nog eens voor de zooveelste maal worden onderstreept. Wie kapitaal vormt, en dus niet verteert, vermindert niet koopkrachtige vraag, draagt niet bij. tot het crisisverschijnsel, doch wendt zijn koopkracht aan op een wijze, die tot meer-koopkracht in de toekomst leidt en de crises in haar oorzaken aantast.

Ten slotte: ik weet, dat het monopolie-karakter van kapitaal bij Oppenheimer van afgeleiden aard is. Op den voorgrond staat het grondmonopolie. Dat jaagt de arbeiders van het land naar de steden, met de bekende gevolgen van loondruk en meer-waarde. Doch hierover wil ik het bij deze gelegenheid niet hebben. Afgeleid of niet-afgeleid: een monopolie blijft een monopolie. En ik meen er in geslaagd te zijn, aan te toonen, dat het kapitaal als categorie niet valt onder het monopoliebegrip, zooals dat door Oppenheimer zelf is opgesteld. Wordt de arbeidskracht beneden haar „,natuurlijke” waarde geruild, dan zal dat niet liggen aan het kapitaal-in-monopoliepositie. Want dat bestaat niet.

Op wel zeer zwakke grondslagen worden nu door Oppenheimer de verschillende bouwsels der liberaal-socialistische toekomstmaatschappij opgetrokken. Met de ondernemerswinst (Profit) verdwijnt de uitleenrente. Wanneer hij zegt 5): „der. Kapitalist

5) Ausweg biz. 51 . 
muss es.. sich gefallen lassen, dass seine Schuldner: Staaten, Kommunen, Haus- und Grundbesitzer und Kommanditäre, den Zins seiner Anlagen Schlag auf Schlag bis auf Null konvertieren", dan vraagt men zich toch af, waar hier de goede trouw gebleven is. Want neemt men den "Zins" af, dan confiskeert men de kapitaalvordering. Het geloofsartikel der uitbuiting verleidt hier tot het plegen van het grofste onrecht. Waar onder onze oogen duizenden en tienduizenden lijden onder het annuleeren van de Russische schuld, daar dringt zich met macht het gevoel op, dat het uitbuitingskarakter der rente wel onomstootelijk, d.i. wetenschappelijk mag vast staan, voor en aleer op zóó ruwe wijze in het bestaall van talloos velen wordt ingegrepen. Geloof alleen mag zulke gevolgen niet op zich nemen. En wanneer te eeniger tijd werkelijk wetenschappelijk vast stond, dat kapitaalwinst en uitleenrente, dat pachtwaarde foro morali als diefstal moesten worden geschandvlekt, dan vraag ik nòg, of diefstal en roof door diefstal en roof kunnen worden uitgedelgd ? Want wie een rentedragend voorschot verleent, staat koopkracht af. Wordt de rente geschrapt, dan heeft men echter niets meer. Men zie de noteeringen der Russen ter beurze. Men zegge niet, dat de hoofdsom zal worden gerestitueerd. Want Oppenheimer spreekt uitdrukkelijk van ,die freudige Voraussicht, dass auch die Staatsanleihen Schlag auf Schlag nach unten konvertiert werden können, ohne dass der Kapitalist, mangels der Möglichkeit einer anderen Anlage, sein Geld zurïckfordern kann.... Es gibt also kein Ausweichen, und das scheint mir für die Finanzminister der schuldenüberlasteten Staaten eine recht tröstliche Aussicht, dass sie in absehbarer Zeit alle Kriegsanleihen auf sage eins pro mille konvertieren können."

Zoo voeren een foutief monopoliebegrip en een onhoudbare rente-opvatting, ") voor welke de benaming ,theorie" te veel eer is, tot aanprijzing van en verheugenis over het Staatsbankroet, en tot berooving van millioenen. offervaardige staatsburgers, die den Staat in den hoogsten nood met hun laatste spaarpenningen - in goed vertrouwen - zijn bijgesprongen. Macchiavelli ? Verblinding?

Oostvoorne, September $1921 . \quad$ H. W. C. Bordewijk.

b) Hoe verward Oppenheimer's denkbeelden zijn over het renteverschijnsel, waarover hil den banvloek uitspreekt, leert Mr. Spanjer op blz. 239 v. van zijn proefschrift. 


\section{MALT T US.}

IV.

De ecrste praemisse van de leer van Malthus.

Het is duidelijk, dat grenzen zooals zij voor de willekeurige verruiming van de voedingsspeelrumte door de wet der verminderende opbrengsten als natuurwet zijn getrokken, de toename der bevolking, wanneer wij deze slechts van physiologisch standpunt beschouwen, niet belemmeren. De eenige grenzen, die de voortplantingsmogelijkheid van alle levende wezens en dus ook van de menschen beperken, zijn de duur der geschiktheid tot het verwekken bij het mannelijk, van de vruchtbaarheid bij het vrouwelijk geslacht. Die beide eigenschappen zijn echter gedurende een zoo lange reeks van jaren aanwezig, dat een volkomen onbelemmerde bevolking zich in veel korter tijd dan 25 jaren zou kunnen verclubbelen. Wanneer Malthus de physiologische vermeerderingspotentie van den mensch tot grondslag had genomen, zou hij het zich zeer gemakkelijk hebben gemaakt. Maar dat heeft hij niet gedaan, niet van de vermeerderingspotentie is bij hem sprake, maar van de vermeerderingstendentic. En deze is bij hem, zoo als wij hebben gezien, niet slechts op een blinde physiologische aandrift gebaseerd, die ongebreideld haar heerschappij over de menschen uitoefent, maar ook op een psychologische factor: op de liefde van het eene geslacht voor de andere, die door overwegingen van de rede kan worden beinvloed en dat inderdaad ook wordt, zoodat niemand waarschijnlijk zooveel kinderen het leven schenkt, als hij physiologisch wel zou kunnen. Die liefde is echter bij hem iets steeds gelijk blijvends, iets constants in den loop der eeuwen en voert tot vereeniging van de geslachten, waarvàn voortplanting het natuurlijk gevolg is. Deze constante factor is de tweede praemisse van de duurzame wanverhouding, die bestaat tusschen feitelijke toeneembaarheid der voedingsmiddelen en in tendentie aanwezige toeneembaarheid van de bevolking.

Zoowel Malthusianen als tegenstanders gebruiken om deze wanverhouding te kenschetsen graag het woord overbevolking, 
maar Budge zegt terecht, dat dit zeer ontraden moet worden. Men moet, wanneer men van de leer van $M$. spreekt het begrip overbevolking als consequentie van deze leer laten varen en slechts spreken van een duturzame neiging tot overbevolking. Een duurzame overbevolking is volgens de leer van $M$. een onmogelijkheid, daar een bevolking nooit langen tijd boven het niveau van de voedingsmogelijkheid kan toenemen. Tijdelijke overbevolking is echter mogelijk door een plotselinge contractie van de voedingsmogelijkheid en cleze kan zich voordoen tengevolge van politieke of natuurlijke catastrophen of door plotselinge veranderingen in het economisch leven. Houden deze laatsten aan, dan treden preventie en repressie dadelijk sterk op, minder huwelijken, minder geboorten, grooter sterfte, de standard of life moet dalen.

Het probleem van $M$. is dus geen probleem van overbevolking, maar van de geringere of sterkere druk van een volk tegen de grenzen van de voedingsmogelijkheid, als consequentie van de tendentie tot overbevolking. Deze druk kan volgens $M$. wel verminderd, doch nooit geheel worden opgeheven.

Vele Anti-Malthusianen gronden hun tegenwerpingen of feiten in de bevolkingsbeweging, die in de laatste $40-50$ jaar de aandacht hebben getrokken. Op grond daarvan komen zij tot de overtuiging, dat de wet van $M$. weliswaar geheel van kracht is voor volken van lagen kultuur, maar dat $z \mathrm{ij}$ voor de het hoogst gekultiveerde volken heeft opgehouden te werken. Deze verschijnselen bestaan in een sedert omstreeks 1875 zoowel in sommige Europeesche kultuurlanden als in de Vereenigde Staten en inzonderheid in Australië aangevangen duurzame daling van het relatief geboortecijfer. En deze daling kan niet worden toegeschreven aan het ongunstiger worden van den economischen toestand. Bijna in al die landen is de welvaart in de loop van de $19 \mathrm{e}$ eeuw snel gestegen. Het is niet verwonderlijk, dat velen die vroeger aan $M$. geloofden, later niet meer met zijn leer konden meegaan of althans de consequenties er niet meer van aanvaarden. Laat zich de daling van het geboortecijfer met de theorie van $M$. vereenigen of hebben wij daarin een ervaringsfeit, dat met $M$. in strijd is? Budge meent het eerste, ik echter het laatste te moeten aanvaarden.

Ook Malthus heeft gezegd, dat met stijgende standard of life 
en daarmee samenhangend, met toenemende beschaving der massa, de preventieve belemmeringen der bevolkingsvermeerdering op de voorgrond komen, terwijl de repressieve meer terugtreden. Maar men zij gewaarschuwd voor de onjuiste opvatting, dat de genoemde geboorteafname niets anders zoude zijn dan een bevestiging van deze Malthusiaansche theorie. Want bij de geboortebeweging van de laatste halve eeuw is juist het opmerkelijke, dat zij in omgekeerde verhouding staat tot de volkswelvaart, dat bij geweldigen groei van den nationalen rijkdom het relatieve geboortecijfer is gedaald. Zoo eenvoudig is het vraagstuk dus niet. Het heeft een aantal theoreën in het leven geroepen, welke zijn verklaring beoogen. Men kan de volgende onderscheiden :

1) Toenemende welstand en beschaving hebben door. middel van psychologische overwegingen .op de wil van den mensch een zoodanigen invloed dat het aantal geboorten beperkt wordt. Deze theorie is van Franschen oorsprong. (1877. Adolphe Bertillon). In Duitschland wordt zij vooral door Mombert en Brentano vertegenwoordigd.

2) Met evengenoemde theorie heeft de volgende veel gemeen, die leert, dat het verlangen, sociaal naar boven te komen, beperking der geboorten veroorzaakt, en dat dit verlangen met toenemende democratie heftiger wordt. (Leroy Beaulieu, Arsène Dumont.)

3) De derde groep beroept zich op het ervaringsfeit, dat de vruchtbaarheid, althans in sommige landen, in de steden vroeger en sneller is afgenomen dan op het platte land. De toenemende neiging van de bevolking tot agglomeratie in de steden zou derhalve schuld dragen. (Jacques Bertillon, J. Cauderlier, Oldenberg).

4) De geboortenafname wordt in verband met den toenemenden trek naar de steden, op de verbeteringen in de fabricatie van middelen ter vermijding van conceptie en op de toenemende bekendheid van de bevolking met die middelen geschoven (Kautsky, Spann).

5) Toenemende welvaart en beschaving bewerken physiologisch een vermindering van de geschiktheid tot het verwekken van kinderen. Gedeeltelijk wordt deze vermindering, in navolging van Spencer, veroorzaakt gedacht door toenemenden hersenarbeid (Mombert), deels ook in navolging van Doubleday door toenemende overvoeding (Bebel).

6) De geboortenafname wordt in samenhang met de geheele bevolkingsbeweging, in 't bijzonder met de sterftecijfers beschouwd 
en in de laatste wordt haar oorzaak gevonden (Seutemann en Budge).

Ook bestaat de meening, dat de vermindering van het geboortencijfer in het geheel niet bestaat, dat zij slechts op statistischen schijn berust (Cauderlier). Deze redeneert als volgt: De sterfelijkheid hangt samen met den stand der medische wetenschap. Deze is nu zoover gevorderd, dat een werkelijke afname is opgetreden, die zich echter meer vertoont bij de lage en hooge, daln bij de voor de voortplanting geschikte leeftijdsklassen. Gevolg daarvan is, dat de bevolking toeneemt zonder dat het geboortecijfer in verhouding meegroeit. Statistisch moet dit te voorschijn komen als daling van het relatieve geboortencijfer. Deze argumentatie deugt echter niet, want niet slechts het relatieve geboortencijfer daalt, maar ook het relatieve vruchtbaarheidscijfer (aantal kinderen per huwelijk) en dit is een zekere toets voor de daling van het aantal geboorten.

Wanneer wij de verschillende theorieën nader bezien, dan kunnen we er één, die van de physiologische afname der geschiktheid, dadelijk ter zijde stellen. Hiervoor is geen enkel eenigszins houdbaar wetenschappelijk bewijs gevonden. Bovendien is men het er tegenwoordig vrijwel over eens, dat bij de afname van de geboorten in onze dagen niet de geschiktheid tot het verwekken, maar de wil daartoe de hoofdrol speelt.

De heerschende leer is diegene, welke de afname der geboorten veroorzaakt acht door den invloed van gestegen welvaart en beschaving. Psychologische overwegingen zijn daarbij het medium, dat een druk uitoefent op den wil tot het verwekken van kinderen (niet op de geslachtdrift). Brentano schrijft m. i. zeer juist: „Das aber, was die Abnahme des Zeugungswillens hervorgerufen hat, sind die Zunahme der Konkurrenz der Genüsse und eine Verfeinerung im Gefühl der Kinderliebe. Die Konkurrenz der Genüsse wirkt sowohl beim . Weib wie beim Mann; indes bei beiden in verschiedener Weise. Beim Weibe macht sie sich geltend, indem sie Unlust hervorruft, das Dasein in Schwangerschaft und Kindbett aufgehen zu lassen; diese Unlust wird um so stärker empfunden, je mannigfaltiger und lockender die Genüsse sind, auf welche es infolge von beiden zu verzichten genötigt ist..., die Hauptursache der Beschränkung des Zeugungswillens des Mannes ist die Erwägung, in wie weit die Beschränktheit seiner Mittel ihn in der 
Befriedigung anderer Ansprüche, die er ans Leben stellt, behindern würde falls er Kinder in gröszerer Zahl in die Welt setzen würde,... nicht anders wirkt die Verffeinerung der Kinderliebe. Mit fortschreitendem Wohlstand pflegen sich die Menschen über das blinde Waltenlassen der animalischen Instincte zu erheben und damit werden sich die Eltern mehr und mehr bewuszt, dasz sie dafür verantwortlich sind, was für Menschen und ob sie deren viele oder weniger auf die Welt setzen." Beter kan het standpunt van de welvaartstheorie niet worden geformuleerd. In denzelfden zin Wolf en Mombert.

Budge bestrijdt dit standpunt op allerlei wijze. In de eerste plaats zegt hij, dat de toegenomen welvaart zelf een gevolg is van de bevolkingsbeweging. Al neemt het volksinkomen nog zoo toe, wanneer de bevolking in verhouding nagroeit, kan het inkomen, dus de welvaart, per hoofd niet grooter worden. Wanneer bewezen wordt, dat het inkomen per hoofd is gestegen, dan bewijst dit dat de bevolking niet even sterk is nagegroeid. Dit willen wij hem gaarne toegeven, want het bewijst niets tegen de theorie. Dat het inkomen per hoofd gestegen is staat vast; niet alleen het geldloon, ook het werkelijke loon is, hoewel in mindere mate, toegenomen in het tijdvak waarop dit alles betrekking heeft en waarin het geboortencijfer lager is geworden. Maar, zegt Budge, daarmee is niet bewezen, dat het laatste een gevolg van het eerste is. Hij is eerder geneigd juist het omgekeerde aan te nemen. M. a.w. de welstand zou toenemen tengevolge van het geringer aantal geboorten. Maar dan vraag ik: wat is dan de oorzaak van dit laatste? Budge zegt: de afname van de sterfte. Maar dan is het niet begrijpelijk, dat, terwijl de geboorten afnemen ondat de voedingsspeelruimte door gedaalde sterfte geen even groot aantal geboorten meer gedoogt, daardoor ooit grooter welvaart kan ontstaan!

- De aanhangers van de welvaartstheorie hebben op inductieve wijze getracht te bewijzen, dat overal waar teekenen van grooter welstand zich voordoen, het geboortencijfer geringer is, dan daar waar armoede heerscht. De meest geliefde manier is de vergelijking van verschillende stadsdeelen, volgens de gemiddelde huurwaarden van de zich daar bevindende huizen en de relatieve geboorten resp. vruchtbaarheidscijfers daarbinnen. Het resultaat is geweest, dat met toenemende huurwaarden de relatieve vrucht- 
baarheid afneemt. Budge beweert dat deze methode vele fouten aankleven, op welke ook reeds Leroy-Beaulieu heeft gewezen. In de rijke stadsdeelen, zegt hij, leven meer oudere menschen, die zich uit zaken hebben teruggetrokken en veel meer ongehuwde dienstboden. Daardoor moet het relatieve vruchtbaarheidscijfer lager zijn. Bovendien zijn veel rijke families een deel van het jaar buiten de stad, en daardoor worden hun geboorten daar gedeeltelijk niet geregistreerd. Ik geloof niet dat deze bezwaren veel gewicht in den schaal leggen. Voor de allergrootste steden hebben zij iets te beteekenen, maar voor dorpen toch zeker niet. Deze kan men in de eerste plaats moeilijk in rijke en andere deelen verdeelen, doch moet men in haar geheel nemen, er worden minder dienstboden gehouden, men reist er minder. En toch blijkt uit de onderzoekingen van Prof. Verrijn Stuart in 40 gemeenten op het land (1901), dat daar evenzeer de vruchtbaarheid afnam met stijgende huurwaarde. En wat het reizen der stedelingen betreft, zou het aantal diergenen groot zijn, die tegen den tijd dat hun vrouw moet bevallen hun vaste woonplaats verlaten ? Wij kunnen dus $\mathrm{m}$. $\mathrm{i}$. deze inductieve bewijsmethode en haar resultaat gerust aanvaarden.

Mombert heeft een anderen weg ingeslagen. Hij vergelijkt de omvang der spaarzaamheid met de vruchtbaarheid en tracht aan te toonen, dat waar het meest gespaard wordt, de vruchtbaarheid het geringst is en waar de spaarzaamheid het meest is toegenomen, de vruchtbaarheid het sterkst is gedaald. In de omvang van de spaargelden resp. in de toename van de spaarzaamheid, ziet Mombert een criterium voor de grootte resp. de toename van welvaart en beschaving. Het resultaat hiervan is voor de welvaarttheorie niet absoluut gunstig geweest, daar de regel niet overal opging. Ik geloof ook niet, dat het sparen een onbedriegelijk teeken is van beschaving. De verschillen in beschaving zijn te gering, dan dat zij zeer op de vruchtbaarheid zouden werken. Want deze methode sluit niet slechts 'de gegoeden buiten, maar evenzeer de gansche middenstand, die evenmin als de rijkeren hun spaargelden naar een spaarbank brengen. In zooverre is: de proefneming te veel tot één klasse bepaald. Daarom mag $\mathrm{m}$. i. het minder gunstige resultaat van deze methode geenszins tot de triumphkreten van Budge voeren, die nu meent, dat de inductieve bewijsvoering geheel mislukt is. In allerlei landen is men op verschillende wijzen tot het resultaat gekomen, dat het geboorEcon. 1921. 
tenaantal met stijgende welvaart (beschaving) afnam. Budge geeft toe, dat dit verschijnsel door redeneering met behulp van de reeds besproken psychologische factoren: toenemende concurrentie van andere levenseischen, verfijning in de kinderliefde, grooter zorg voor de toekomst der kinderen bij toenemende welvaart en beschaving, wel zeer plausibel wordt, althans voor zekere lagen van de bevolking. Men zou kunnen opmerken, dat het toch vreemd is, on dan dezelfde resultaten op inductieve wijze verkregen, te verwerpen. Later beweert Budge dan echter, dat de lagen van de bevolking, waarop die psychologische overwegingen grooten invloed hebben, slechts zeer dun zijn, dat de rijkste lieden er in het geheel niet toe behooren, maar slechts die klasse, die tengevolge van beroep of stand niet in staat is, de voordeelen van toenemende productiviteit van den arbeid mee te genieten (beambten, leeraren etc.) Deze lagen zouden veel te dun zijn om een beslissenden invloed te doen gelden op de geboortenafname. Ik ben het geenszins met Budge eens, dat de psychologische factoren slechts op een zóó gering deel van de bevolking werken, $\mathrm{jk}$ geloof dat de rijkste lagen er ook ten zeerste door beinvloed worden, zij het dan ook niet zoo zeer in den vorm van economische, als wel van hedonistische overwegingen (waarover later meer), en verder ook de kleine burgerij, die talrijk is en die wel meegenietende van de toenemende productiviteit van den arbeid, niet slechts de éénmaal bereikte standard of life wil bewaren, maar een hoogere ambieert, nu zij eenmaal het geluk van een passabelen welstand heeft gesmaakt. En al deze klassen samen kunnen $\mathrm{m}$. i. reeds een zeer grooten invloed uitoefenen op het totale geboortecijfer, zóó zelfs dat als eenerzijds bij de allerlaagste klasse het geboortecijfer niet nog vrij hoog was en als anderzijds de sterfte niet zoo was afgenomen, het cijfer der geboortenoverschotten in sommige landen met dezelfde sprongen zou zijn gedaald als dat der geboorten.

Budge komt dan vervolgens met deze weinig stringente redeneering: het is niet in te zien, waarom in de groote lagen van het arbeidende volk, hetwelk doordrongen(?) is van het bewustzijn, dat het voortdurend meewerkt tot een stijging van de productiviteit van den arbeid, 't welk ziet, dat de vraag naar arbeid steeds snel aangroeit (n.b. : 1912), dat het loonniveau zich voortdurend. verheft en dat bovendien vervuld is van de hoop op een tijd, waarin het den proletarier nog veel beter zal 
gaan dan tegenwoordig, waarom in een zoodanige bevolking die psychische overwegingen zullen bewerken, dat het kindertal gering wordt gehouden ? En vervolgens : ,,kan de arbeider niet overtuigd zijn, ook bij de meest verfijnde kinderliefde, ook bij de grootste zorg voor de toekomst van zijn kinderen, dat elk daarvan, ook bij een groot aantal, in de toekomst misschien nog beter kan leven dan hij zelf ?" En daarbij komen dan volgens B. ook nog psychische factoren, die een groot kindertal in de hand werken: de wensch naar een groote familie, de zucht om in de ouderdon door een groot aantal krachtige verzorgers omgeven te zijn, de kinderliefde der moeder.

De overtuigingskracht van deze redeneeringen is zeer gering en sedert den oorlog" nog aanzienlijk geringer geworden. Het is niet zeer waarschijnlijk, dat de arbeider voortdurend van toekomsticlealen is vervuld, in elk geval kan hij daarmee geen groot kindertal voeden; veel sterker zal de behoefte van het oogenblik op hem werken en deze gebiedt hem zijn kindertal te beperken. En de psychische factoren, die Budge aanvoert, zijn bovendien heel vreemd : Zou de wensch naar een groote familie als zoodanig wel ooit bij die bevolkingsklassen bestaan ? Het schijnt dat Budge (in tegenstelling tot Malthus) hier den mensch een directe wil tot het verwekken van kinderen toeschrijft, (een fout, die hijzelf aan Brentano verwijt), dat hij in de meening verkeert, dat de mensch onder alle omstandigheden juist een zóó talrijke familie wenscht te bezitten, dat zijn vroegere standard of life niet in gevaar komt. Deze meening heeft hij dan in Malthus ,hinein interpretiert". En is het moederlijk instinct bij de vrouw gericht op het hebben van zooveel mogelijk kinderen of op het hebben van kinderen zonder meer? Ik zou zeggen dat het laatste meer waar is, dat twee of drie kinderen dat instinct in normale gevallen wel zullen bevredigen.

En zoo kom ik dus tot de conclusie, dat Budge op zeer losse gronden beweert, dat stijgende welvaart en afnemend kindertal niet in een psychologisch causaal verband staan, een zeer geringe bevolkingslaag daargelaten. En het komt mij voor, dat Budge noch het inductieve, noch het deductieve bewijs van de welvaartstheorie met succes heeft bestreden.

De theorie der capillarité sociale mag $\mathrm{m}$. i. niet als onafhankelijke theorie ter verklaring van de geboortenafname worden 
genoemd. $Z \mathrm{ij}$ is ten nauwste verbonden met de welvaarttheorie en voor zoover Budge haar met andere argumenten dan de vorige bestrijdt, ben ik het met hem eens : b.v. waarom zou die sociale opdrift plotseling omstreeks 1870 in de kultuurlanden zijn ontwaakt? Doch als onderdeel van de welvaartheorie, speciaal voor zekere lagen van de bevolking, heeft zij stellig beteekenis en vanuit dit gezichtspunt kan worden toegegeven, dat een „capillarité sociale" de toenemende beschaving steeds vergezeld heeft.

lets dergelijks is het geval met de meening, dat de afname der geboorten te wijten is aan de algemeener bekendheid en verspreiding van anti-conceptioneele middelen. Zonder twijfel hebben verbeteringen in de fabricatie daarvan plaats gegrepen, maar deze zijn veroorzaakt door de grooter wordende vraag naar goede dergelijke middelen. Bekendheid met die middelen is niet voldoende, er moet een wil zijn om ze te gebruiken. En de psychologische basis voor dien wil levert de welvaarttheorie. Deze middelen vormen dan ook niets anders dan de technische kant van genoemde theorie en kunnen geenszins voor een andere onafhankelijke verklaring de fundamenten leveren. Dit blijkt bovendien ook wel hieruit, dat in Frankrijk het geboortencijfer in de eerste helft der $19 \mathrm{e}$ eeuw, toen die middelen nog zeer primitief waren en bovendien schadelijk, sterker is gedaald dan in de tweede helft van de $19 \mathrm{e}$ eeuw. - En ook schijnt het absoluut onjuist, om de toenemende bekendheid met die middelen te wijten aan de agglomeratie in de steden, daar de afname der vruchtbaarheid lang niet overal in de steden grooter is geweest dan op het land.

Dit laatste hebben velen gemeend, vooral in Duitschland, waar het statistisch ook waar bleek te zijn. Doch noch in Frankrijk, noch in Engeland was dit het geval, in Frankrijk is zelfs het omgekeerde waar, zoodat men heeft beweerd, dat de oorzaak van de fransche bevolkingsstagnatie in de te geringe ontwikkeling van de fransche industrie was gelegen, waardoor werd verhinderd dat groote steden industrieele bevolkingen kregen. In elk geval wordt het kleine geboorten-overschot in Frankrijk geheel geleverd door de industrieele departementen en niet door de agrarische.

De verschillende verklaringen opgesomd hebbende, die voor het dalend geboortecijfer zijn gegeven, kom ik tot de slotsom, dat de welvartheorie, met de theorie der sociale opdrift als onderdeel 
en met de verbeterde anticonceptioneele middelen als instrument, in de vorm van preventie in het huwelijk, de gewenschte verklaring geeft. Of deze verklaring past in Malthus' leer, of dat zij feiten doet kennen, die $M$. niet heeft voorzien, zullen wij later onderzoeken.

Het schijnt mij echter wel de moeite waard, ons nog eerst te wenden tot de verklaring, die Budge van de daling geeft. Volgens hem is geen der genoemde theorieën in staat de oplossing te geven, en dit komt, beweert hij, ondat de beweging der geboorten geisoleerd werd beschouwd. Slechts wanneer wij haar in verband met de geheele bevolkingsbeweging in oogenschouw nemen, zullen wij de ware oorzaak van de daling kunnen ontdekken en dan zullen wij ook gemakkelijk kunnen nagaan, in hoever dat pliaenomeen met de leer van Malthus overeenstemt.

De bevolking groeit steeds daar, waar de voedingsmiddelen toenemen, zegt de tweede these van Malthus. Sinds het begin van de 19 e eeuw, zoo merkt Budge op, zijn de voedingsmiddelen als nog nimmer vermeerderd en gelijktijdig is in bijna alle kultuurstaten de bevolking toegenomen als nog nooit te voren. Tusschen 1815 en 1910 is de bevolking in Duitschland, Engeland en Schotlart, Nederland, Zweden en Noorwegen meer dan verdubbeld, in Oostenrijk bijna. In Frankrijk is de bevolking echter slechts met $37.3 \%$ gegroeid. Van 1870 tot 1905 groeide de bevolking van het Duitsche rijk met $47.7 \%$, in Engeland en Schotland met $41.4 \%$, in Rusland met $42.2 \%$, in Nederland met $42.5 \%$, in Frankrijk slechts met $6 \%$.

- Voor de bevolkingstoename van de laatste 30 tot 40 jaar is het nu juist karakteristiek, dat zij, afgezien van de half beschaafde Oost-Europeesche Staten, gelijktijdig met en trots de voortdurende daling van het geboortecijfer plaats greep. $Z i j$ werd, volgens Budge, mogelijk gemaakt doordat het sterftecijfer in nog sterker mate daalde dan het geboortecijfer.

Van omstreeks 1875 af treedt een duidelijke afname van het sterftecijfer aan het licht en de hoofdoorzaak hiervan is een omstandigheid, die niets te maken heeft met de bevolkingsbeweging, nl. de vooruitgang van de medische wetenschap en de hygiene. Juist het feit, dat die daling van de sterfelijkheid terug te brengen is tot een oorzaak, die van de bevolkingsbeweging geheel onafhankelijk is, zoodat wisselwerking is uitgesloten, geeft volgens Budge de oplossing van het raadsel der afnemende geboorten 
aan de hand. In een gegeven land is de bevolkingsgrootte afhankelijk van den gegeven omvang der potentieele voedingsspeelruimte, in verband met een gegeven standard of life. Deze bevolkingsgrootte kan tot stand komen of door talrijke geboorten. en talrijke sterfgevallen, of door minder talrijke sterfgevallen, die dan echter ook een vermindering der geboorten noodig maken. Veranderen in een land de omstandigheden in zoodanige richting, dat de sterfgevallen minder talrijk worden — en dat is juist bij vooruitgang van medische wetenschap en hygiene het geval dan moet ceteris paribus het geboortencijfer dalen.

Hier moet ik Budge even in de rede vallen: dit alles kan alleen waar zijn bij constante welvaart. Want als de geboorten mocten afnemen omdat de sterfte afneemt, dan kan de welvaart nooit stijgen, alle toename van productiviteit van de arbeid zou niets baten, het gevolg zou alleen zijn, dat de geboorten dan niet meer moesten afnemen en daar psychologische motieven voor Budge niet schijnen te bestaan, zouden zij, de geboorten, dus oogenblikkelijk toenemen en de welvaart zou niet stijgen. Deze is echter in die perioden wel gestegen.

Op welke wijze werkt nu volgens Budge het afnemen der sterfelijkheid op het geboortencijfer? Natuurlijk niet automatisch, maar zóó dat de afnemende sterfte op den wil van het zich voortplantende deel der bevolking inwerkt. En dit gebeurt op verschillende manieren. In de eerste plaats is de afname te bespeuren in de sterfelijkheid der kinderen tusschen 2 en 10 jaar, deze is vrij belangrijk; vervolgens in de zuigelingensterfte, die weliswaar in Duitschland weinig is afgenomen, maar in andere landen (b.v, Nederland) aanzienlijk. Het gevolg is dat ouders, nu minder kinderen sterven, ook mindẹr "lacunes" te vullen hebben. Budge is overtuigd, dat verreweg de meeste ouders, in geval zij een kind beneden 10 jaar verliezen, snel voor een remplacant zorgen. $\mathrm{Nu}$ komt een dergelijk verlies minder dikwijls voor, dus het aantal geboorten neemt af.

Maar ook in de oudere leeftijdsklassen is de sterfelijkheid heel wat minder geworden, en dit oefent eveneens invloed uit op de wil tot het verwekken van kinderen. Immers die klassen zijn grooteudeels half of geheel improductief en vormen een economische last voor de vol-productieve klassen. Daarom gaan deze later trouwen en verwekken minder kinderen. Verder wordt tengevolge van die afgenomen sterfelijkheid, de mogelijkheid van 
het krijgen van erfenissen geringer, zij komen althans later. En ten slotte treden meer menschen in den productieven leeftijd, daardoor wordt de concurrentie scherper, de struggle for life zwaarder etc. etc. Op al deze wijzen werkt dus volgens Budge de afgenomen sterfte op de menschelijke wil. En hij komt tot het besluit, dat de afname van het geboortencijfer veroorzaakt wordt door de afnemende sterfte, die wederom wordt veroorzaakt door factoren, die niets met de bevolkingsbeweging te doen hebben.

Daaruit volgt dan voor hem, dat deze afname der sterfte de causa causans is van de veranderingen' in de bevolkingsbeweging der laatste decennia. Was niet tegelijk met de afname der sterfelijkheid ook het geboortencijfer verminderd, dan was de standard of life gedaald, hij had in elk geval nooit kunnen rijzen.

Op deze gansche theorie is uiterst veel aan te merken. De voornaamste wijze waarop Budge het afnemende sterftecijfer op den menschelijken wil laat werken, berust op een kapitale fout. Ondat minder jonge kinderen sterven, worden er mincer remplaçanten verwekt en vermindert dus het geboortencijfer als cijfer. Juist! Maar niet het aantal kinderen! Budge verwart hier het aantal geboorten en het aantal kinderen. Het aantal kinderen blijft op deze wijze even groot, m.a.w. de bevolking blijft evenzeer toenemen (al merkt men dat niet uit het geboortencijfer), trots het afnemende sterftecijfer. De standard of life moet dus bij constante productiviteit onmiddellijk gaan dalen. Hieruit blijkt m.i., dat de sterftevermindering geenzins op deze wijze op den wil van den mensch werkt, dat zij althans niet den minsten invloed heeft op het absolute aantal doorlevende kinderen.

Verder moet zonder twijfel het afnemen der geboorten weer invloed hebben op de sterfte. Immers minder geboorten — minder sterfgevallen. (Volgens Budge gaat dit dan zeker ,gleichsam in einem ewigen (ircul"). In ieder geval is het onmogelijk, dan van de vermindering der sterfte als causa causans te spreken.

Wat verder het grooter worden van de productieve lagen betreft: de arbeiders trouwen over het algemeen op een leeftijd, dat de ouders nog niet ondersteund behoeven te worden, bij het trouwen denken zij daar nog niet aan. Zijn zij zóó arm, dat zij later gaan trouwen, omdat $z i j$ haast geen huisraad kunnen koopen (hetgeen wegens het latere erven tegenwoordig volgens Budge veel zou vóórkomen), dan is er m.i. wel geen sprake van, dat zij zich in sexualibus aan eenige rem zullen storen, want dan 
behooren zij tot die laagste klassen waar de libido nog geen concurrentie heeft. Germinal!

Verder is het opmerkelijk dat Budge zijn theorie grootendeels via dezelfde psychologische overwegingen laat werken, die hij bij de welvaartstheorie zoo scherp heeft gelaakt en waarvoor hij den arbeider ontoegankelijk achtte. De inconsequentie is te groot! De welvaartheorie staat er echter des te vaster door.

De preventie wordt verder door Budge nu plotseling ook in de arbeiderskringẹn als de gewoonste zaak van de wereld beschouwd. Maar de vermeerdering van de bevolking is zeker niet aan die lagen te danken die deze preventie beoefenen, maar juist aan de andere. De verbeterde hygienische toestanden hebben $n u$ een compensatie geschapen tegen de geboortenafname in ruimen kring. Maar wanneer de sterfelijkheid eens stationair wordt -en dit moet toch vroeg of laat gebeuren - dan kan men zeker een geweldige inkrimping van het geboorten-overschot verwachten. De afname der sterfelijkheid is, zooals ik reeds heb gezegd, geenszins een voldoende oorzaak voor het afnemen der geboorten, slechts is zij een reden, dat het geboorten-overschot niet met een gelijk bedrag als het geboortencijfer is verminderd.

Ons rest dus nu nog na te gaan, in hoeverre onze opvatting van de latere bevolkingsbeweging, strookt met de leer van Malthus.

Budge meent dat zijn verklaring van de geboortenafname volkomen in het stelsel van Malthus past. De verklaring uit de snelle vermindering van het sterftecijfer is volkomen in overeenstemming met Malthus. Hij citeert daarbij de volgende woorden van $M$. : In landen die van nature ongezond zijn en die om de een of andere reden een groote sterfelijkheid vertoonen, zal de preventieve beperking weinig heerschen, ongekeerd echter zal in landen, die van nature gezond zijn en waar de preventieve beperking op duidelijke wijze zeer sterk werki, de repressieve slechts in geringe mate optreden m.a.w. de sterfelijkheid zal daar gering zijn. Maar Budge vergist zich. Men kan hieruit absoluut niet lezen, dat medische en hygienische verbeteringen noodzakclijk de preventieve beperking versterken. De hygienische verbeteringen als zoodanig leiden volgens Malthus geenszins noodzakelijk tot vermijding van geboorten. Wolff is van meening, dat Malthus veeleer er toe geneigd zou zijn om hygienische verbetering als ongunstig voor de arbeiders te beschouwen, daar zij hun de voordeelen van een 
economische „Aufschwung" zou kunnen doen verliezen en hen op den ouden standard of life zou kunnen vasthouden. Door te groote onderlinge concurrentic, die een gevolg is van het grooter aantal, dat in leven blijft.

En dit schijnt ook mij juist toe.

Het komt mij voor dat de eerste praemisse van Malthus zonder haar consequentie's en cenigszins oppervlakkig genomen, wel kan blijven gelden. De constantie van de geslachtelijke liefde zonder meer, is geenszins door de nieuwste feiten weerlegd. In tegendeel; het preventieve verkeer geeft juist de mogelijkheid aan de geslachten om zich vrijwel onbeperkt daaraan over te geven, slechts het natuurlijke gevolg, de geboorte van kinderen wordt verhinderd. En het is dus ook niet waar, dat, zooals Brentano beweert, ten aanzien van de bevrediging der geslachtelijke instincten, de wet van Gossen zou gaan werken, daar het tegenwoordig zeer wel mogelijk is, om volledige bevrediging te erlangen zonder door het verwekken van een groot aantal kinderen, het voldoen aan andere behoeften onmogelijk te maken.

Maar is het niet eenigszins oppervlakkig, om de woorden van deze praemisse te laten gelden, terwijl de door Malthus daar steeds vast aan verbonden gedachte: vereeniging der geslachten $=$ voortplanting, geenszins meer waar genoemd kan worden? Weliswaar tracht Budge aan te toonen, dat Malthus de preventiemiddelen zeer goed gekend heeft, maar hij slaagt er niet in mij te overtuigen.

In de eerste plaats dit: uit de op bladz. 560 onder 1) en 2) genoende, aan Malthus ontleende opsomming, blijkt ten duidelijkste, dat hij aan preventief verkeer in het huwelijk zelf niet heeft gedacht. Hoe anders te verklaren, dat hij uitdrukkelijk spreekt van allerlèi geslachtsverhoudingen sub. 1), waaronder het huwelijk echter - hoewel toch de belangrijkste - geheel ontbreekt, terwijl hij overigens zelfs spreekt, (er dus blijkbaar wel aan gedacht heeft) over de ,praktijken ter verberging 12) van de gevolgen" waarvan ?: van ,onwettige" sexueele verhoudingen.

Preventie in het huwelijk schijnt niet bij hem te zijn opge-

12) Praktijken ter voorkoming van gevolgen worden niet besproken. Trouwens uit het geheele verband blijkt telkens, dat huwelijk en voortplanting onverbrekelijk zijn samengekoppeld in zijn gedachtengang (,the restraint from marriage", vgl. noot 1 op bldz. 561). 
komen; 13) zoo hij er al eens aan mocht hebben gedacht, heeft hij haar bij zijn opvattingen natuurlijk onder de rubriek der immoreele methoden gerangschikt, edoch zoo hij haar slechts immored had gevonden, zou hij haar zonder twijfel bij de overige immoraliteiten hebben genoemd. $\mathrm{Hij}$ noemt haar niet, ergo beschouwt hij haar als een absoluut te negligeeren anomalie of als een voorstel van Condorcet, dat toch nooit ingang zou vinden. Had hij er meer in gezien dan een uitzondering, dan had hij van het aanhoudend drukken van de bevolking tegen de voedingsgrens niet kunnen spreken en ook niet gesproken. Hij was er zelf vast van overtuigd, dat bij algemeen beoefende preventie in het huwelijk, de praemisse voor de geldigheid van zijn wet verviel. Hij zegt zelf : ,Wanneer elk echtpaar slechts door de desbetreffende wensch het aantal zijner kinderen zou kunnen beperken (sic), dan moest men zonder twijfel vreezen, dat de traagheid van het menschdom geweldig zou toenemen en dat noch de bevolking der afzonderlijk landen, noch die van de geheele aarde ooit haar natuurlijke en behoorlijke grootte zou bereiken" 14 ).

De tendentie van het dringen tegen de voedingsgrens, die de

13) Oppenlieimer is van dezelfde meening: „Die sog. neo-malthusianischen Praktiken, die wohl die Kindererzeugung, aber nicht den Geschlechtsverkehr einschränken, lagen auszerhalb seines Gesichtskreises." Theorie der reinen und Politischen Oeconomie, 4e druk p. 624.

14) p. 511 (appendix van 1817).

Nadat een Mr. J. Grahame in een boek „An Inquiry into the principle of Population" Malthus geheel ten onrechte had beschuldigd, dat hij "recommended immediate recourse to human efforts to the restraint prescribed by Condorcet for the correction or mitigation of the evil" zegt hij eerst: I have never adverted to the check suggested by Condorcet without the most marked disapprobation. Indeed I should always particurlarly reprobate any artificiel and unnatural modes of checking population, both on account of their immorality and their tendency to remove a necessary stimulus to industry. If it were possible for each married couple to limit by a wish the number of their children, there is certainly reason to fear that the indolence of the human race would be very greatly increased, and that neither the population of individual countries nor of the whole earth would ever reach its natural and proper extent.

Deze laatste zin geeft duidelijk weer (,if it were possible...") dat Malthus het niet "possible" aclitte, natuurlijk minder om technische dan om psychologische redenen. En hij zegt zelf, dat if it were possible... de bevolking waarschijnlijk niet slechts niet tegen de voedingsgrens zoude dringen, doch zelfs niet haar natuurlijke en gewenschte uitbreiding erlangen. M.a.w. dat dan zijn these niet meer zou opgaan. 
kern vormt van de Malthusiaansche leer, bestaat slechts zoolang, als geslachtsliefde en voortplanting onverbrekelijk verbonden zijn. Maar dan ook steeds.

De eerst praemisse van $M$. met de noodzakelijke consequentie's welke tot.de belangrijkste deelen van zijn leer behooren, is dus niet meer te aanvaarden. Malthus heeft de psychologische feiten, die de welvaartstheorie verklaart, niet voorzien, hij heeft daardoor de motieven voor de preventie in het huwelijk niet voldoende gekend en daardoor niet op de eventueele belangrijkheid van deze preventie acht geslagen. De groote consequentie van $z$ ijn leer : het drukken van de bevolking tegen de grenzen der voedingmogelijkheid kan derhalve in tijden van rationeel doorgevoerde en min of meer algemeene beoefende preventie vervallen en daarmede cle waarde van zijn theorie voor die tijden, benevens, en dat is de hoofdzaak, de ellendige gevolgen, welke die theorie aangeeft.

Budge, na de welvaartheorie verworpen te hebben en na zijn verklaring uit de afname der sterfelijkheid zoo goed en kwaad als het ging in het Malthusiaansche systeem gewrongen te hebben, ziet alle bezwaren, die hierboven zijn geopperd, over het hoofd of acht hen niet in staat $M$. te schaden. Door allerlei vreemde interpretatie's wil hij ons ten slotte doen gelooven, dat $M$. voor de mogelijkheid van cene ruime verbreiding van preventie in het huwelijk een plaats in zijn systeem had opengelaten. Echter met één voorbehoud : preventie in het huwelijk heeft $M$. wel verwacht, doch slechts veroorzaakt door. economische motieven 15) (t.a.p. p. 200).

Budge vraagt nu : $Z_{\text {ijn }}$ er eenige voorteekenen waar te nemen, dat het kindertal willekeurig wordt beperkt, zonder dat de daarop betrekking hebbende wil der ouders door eenigerlei factoren van economischen aard zijn beinvloed? Want slechts als dit zoo is, heeft Malthus ongelijk.

Budge beantwoord deze vraag natuurlijk ontkennend, maar ik kan, als ik mij een moment op zijn standpunt plaats, zelfs hierin niet met hem meegaan.

Ik geloof, dat niet slechts economische overwegingen op den

15) Ik meen al duidelijk te hebben aangetoond dat $M$. in zijn leer geen rekening heeft gehouden met de preventie in het huwelijk, zooals zij zich in de latere jaren heeft voorgedaan en dus ook niet met de aard der motieven, welke daartoe hebben geleid. 
wil van ouders invloed hebben, vooral niet in de hoogst beschaafde kringen van oude kultuurlanden. Hedonistische motieven spelen hier een hoofdrol. Hoe anders de regel van Juvenalis (Sat. VI. 593) te begrijpen : ,sed jacet aurato vix ulla puerpera lecto." ?

Evenzoo Mrs. Braby : Modern marriage etc. p. 180 : „A good many women deliberately forego their prospect of motherhood because it would interrupt their pleasures, spoil the hunting season, interfere with their desire to travel or their craze for games."

Gezien de taak, die de natuur op dit stuk de vrouwen heeft opgelegd, is het geen wonder, dat zich juist bij haar bovengenoemde motieven voordoen. Bij den man zullen het menigmaal égards voor zijn vrouw zijn, die bewerken dat zijn wensch een talrijk kroost te bezitten zich niet realiseert.

Budge ontkent, zooals wij gezien hebben, andere motieven dan de economische, maar het dalen van de geboorten-overschotten in vier van de meest gecultiveerde landen geeft hem toch te denken. Als de productiviteit van den arbeid in die landen toenemende is, dan kan hij het niet met zijn afnemend sterftecijfer verklaren en hij zou moeten besluiten tot niet-economische preventie in het huwelijk. Om dit te vermijden verkondigt hij, dat de economische prosperiteit van Engeland en Schotland, Zweden, Frankrijk en Australie vermindert (in 1912). Hij houdt zeer wijdloopige redeneeringen, (t.a.p. bladz. 203 seq.) die er geenszins in slagen ons te overtuigen. Vooral voor Frankrijk, waar de geboortenoverschotten zoo aanzienlijk zijn achteruit gegaan, valt het zeer moeilijk om te bewijzen, dat de voedingsspeelruimte geen grooter aantal geboorten toeliet. Dat ook dáár de massa. nog niet met haar toestand tevreden is, dat in zekeren zin ook dáár de bevolking tegen de grenzen der voedingsmogelijkheid drukt, laat zich niet loochenen. Maar dit drukken is iets héél anders dan het door Malthus bedoelde, waarbij de standard of life steeds gevaar loopt. Ware dit niet zoo, dan zou de wet van Malthus op de gemeenplaats neerkomen, dat het meerendeel der menschen niet met zijn lot tevreden is.

De eenige mogelijkheid om de leer van $M$. te redden bestaat daarin, dat men zegt, dat de algemeen geworden preventie in het huwelijk jets noodzakelijk voorbijgaands zal moeten zijn, omdat men aanneemt, dat de volken die haar zullen beoefenen, door andere, die zulks nalaten, zullen worden overwonnen en ver- 
drongen. Als die volken dan van de wereld verdwijnen en de andere, de z.g. ,gezondere" blijven bestaan, dan heeft Malthus, van wereldhistorisch gezichtspunt, gelijk gehad. Maar voor de „verdwijnende volken" had hij dit niet en de toekomst moet het andere nog leeren.

Hopen wij inmiddels, dat deze z.g. ",gezondere". volken wijzer zullen worden, voordat $z \mathrm{ij}$ door hun aantal genoodzaakt zullen $z \mathrm{ijn}$, de leer van Malthus weer op deze bloedige wijze te steunen!

RIES. 